İşletme Akademisi Dergisi
$2021,2(2): 155-175$
Dol:10.26677/T1010.2021.784
Dergi web sayfasl: www.isakder.org

Araștırma Makalesi

\title{
Tarım İşletmelerinde Bahçe Bitkileri Üretim Faaliyetlerinin TMS 41'e Göre Muhasebeleştirilmesi
}

\section{Erdi YALÇIN}

erdi 0424@hotmail.com, www.orcid.org/0000-0003-0410-5670

\section{Dr. Öğr. Üyesi Utku ŞENDURUR}

Ağrı İbrahim Çeçen Üniversitesi, İktisadi ve İdari Bilimler Fakültesi, Ağrı, Türkiye. ussndurur@agri.edu.tr, www.orcid.org/0000-0002-8303-4315

Öz

Tarım Sektörü, insanların beslenme barınma vb. ihtiyaçlarını karşılamak, farklı sektörlere veri ve kaynak sağlama konusunda önem arz etmektedir. Ayrıca ekonomiye sürekli veri sağlaması ve değer katmasından dolayı önemini her zaman koruyan bir sektör niteliğindedir. Tarım alanında faaliyetini sürdüren ticari nitelikteki küçük işletmelerin sayılarının her yıl giderek artması, tarımda uygulanacak muhasebe uygulamalarının daha da önem kazanmaya başlamasına neden olmuştur. Tarımsal faaliyetler ve bu faaliyetlerle ilgili canlı varlıkların muhasebeleştirme yöntemlerini düzenleyen Tarımsal Faaliyetler Standardı (TMS 41), canlı varlıklar ile tarım ürünlerinin değerlemesi konusunda gerçeğe uygun değerleme yaklaşımını benimsemektedir. Bu çalışmada, nitel bilimsel araştırma yöntemlerinden biri olan örnek olay incelemesi yöntemi kullanılmıştır. Araştırmaya konu olan tarımsal işletme Van ilinde seracılık faaliyetlerini sürdürmektedir. Serada üretimi gerçekleştirilen domateslerin dikiminden hasat edilme sürecine kadar yapılan işlemlerin, TMS 41 çerçevesinde muhasebe işlemleri yapılmıştır. Ayrıca hasat noktasından sonra stoklara giren tarımsal ürünlere ait gider kalemleri kendi alanlarında maliyetlendirilerek gerçek maliyet değerlerine ulaşılmaya çalışılmıştır. Çalışmada yapılan muhasebe kayıtları Eylül 2018 tarihinde Kamu Gözetimi Muhasebe ve Denetim Standartları Kurumu (KGK) tarafından hazırlanan Finansal Raporlama Standartlarına uygun yeni hesap taslağına uygun şekilde yapılmıştır.

Anahtar Kelimeler: Tarımsal İşletmeler, TMS 41, Seracılık Faaliyetleri

Makale Gönderme Tarihi: 24.03.2021

Makale Kabul Tarihi: 16.06 .2021

Önerilen Atıf: Yalçın, E., Şendurur, U. (2021). Tarım İşletmelerinde Bahçe Bitkileri Üretim Faaliyetlerinin TMS 41'e Göre Muhasebeleştirilmesi, İşletme Akademisi Dergisi, 2 (2): 155-175.

(C) 2021 İşletme Akademisi Dergisi. 


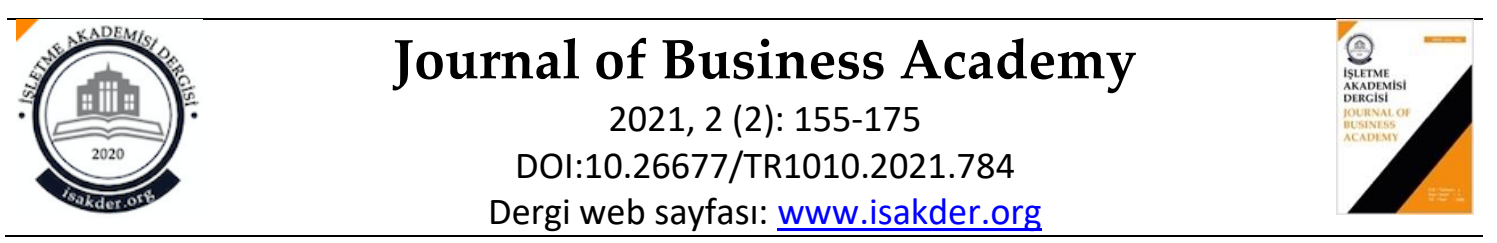

$\underline{\text { Research Article }}$

\title{
Accounting of Garden Plants Production Activities in Agricultural Enterprises According to IAS 41
}

\section{Erdi YALÇIN}

erdi_0424@hotmail.com, www.orcid.org/0000-0003-0410-5670

\section{Assist Prof. Utku ŞENDURUR}

A ̆grı İbrahim Çeçen University, Faculty of Econonics and Adminitrative Sciences, Ağrı, Turkey. ussndurur@agri.edu.tr, www.orcid.org/0000-0002-8303-4315

\begin{abstract}
Agriculture has always held its value an important sector for providing nutrition and accommodation for people and input for other sectors as well as creating employment and financial value in the market. Accounting practises in agriculture has gained importance over the past years because of the increasing number of the commercial business in agriculture sector. Agricultural activities consist of livestock and farm products. The Agricultural Activities Standard (TAS 41), which regulates the transactions occurring in agricultural activities, adopts a fair valuation approach for the valuation of biological assets and agricultural products. In the prepared study, the study was conducted with the case study method in the qualitative research method branch from the scientific research method. The agricultural enterprise subject to the research continues its greenhouse activities in the province of Van. The transactions made from the planting of the tomatoes produced in the greenhouse to the harvesting and during the sales are made in accordance with the framework of IAS 41 . The accounting records made in the study were made in accordance with the new account draft in accordance with the Financial Reporting Standards prepared by the Public Oversight Accounting and Auditing Standards Authority (KGK) in September 2018.
\end{abstract}

Keywords: Agricultural Businesses, IAS 41, Greenhouse Activities

Received: 24.03.2021

Accepted: 16.06 .2021

\section{Suggested Citation:}

Yalçın, E., Şendurur, U. (2021). Accounting of Garden Plants Production Activities in Agricultural Enterprises According to IAS 41, Journal of Business Acamedy, 2 (2): 155-175.

(C) 2021 Journal of Business Academy. 


\section{GİRiş}

İnsanoğlunun varoluşundan beri tarımsal ürünlerle ilgili faaliyetler kırsal kesimde yaşayan birey ya da çekirdek aile işletmeleri tarafından yapılmaktaydı. Günümüzde dünya nüfusunun giderek artmasına bağlı olarak insanların tarımsal ürünlere olan talep artışı, tarım sektöründe teknoloji kullanımının yaygınlaşmasına yol açmıştır. Ayrıca devlet tarafından tarımsal işletmelere sağlanan teşvikler tarım sektöründe sermaye yoğun yatırımlarda önemli düzeyde artışlar meydana getirmiştir.

Tarım alanında son yıllarda yaşanan gelişmeler sonucunda tarım muhasebesi tarım sektöründe faaliyet gösteren işletmeler için giderek önem kazanmaya başlamıştır. Yaşanılan ekonomik ve teknolojik gelişmeler sonucunda meydana gelen ihtiyaçları karşılamak amacıyla yürürlüğe giren uluslararası muhasebe ve finansal raporlama standartlarıla beraber 1 Ocak 2003 tarihinde Uluslararası Muhasebe Standardı (UMS 41) 41 numarada yayınlanmıştır. Uluslararası muhasebe standartları yayınlanmasından itibaren 1 Ocak 2005 tarihinde Sermaye Piyasası Kurulu (SPK), borsaya kayıtlı tarım işletmelerinin tarımsal faaliyetlerini düzenlemek amacıyla bir tebliğ (SPK 31) yayınlamıştır. Yaşanılan bu gelişmelerden sonra 24 Şubat 2006 tarihinde Tarımsal Faaliyet Standardı (TMS 41) yürürlüğe girmiştir. Yapılan bu düzenlemelerin en önemli amacı bütün ülkelerde tarım ve canlı varlıklarla uğraşı içinde olan tarım işletmelerinin tarımsal faaliyetlerle alakalı muhasebe uygulamalarında bütünlüğü hedeflemektedir.

Bu çalışmada, Van ilinde seracılık faaliyetlerini sürdürmekte olan tarımsal işletmede araştırma yapılmıştır. Serada üretimi gerçekleştirilen domatesin bahçe dikiminden hasat edilme noktasına kadar yapılan işlemlerin, TMS 41 çerçevesinde muhasebe işlemleri yapılmıştır. Ayrıca ilgili gider kalemlerini kendi alanlarında maliyetlendirilerek, gerçek maliyet değerlerine ulaşılmaya çalışılmıştır. Çalışmada yapılan muhasebe kayıtları 13 Eylül 2018 tarihinde Kamu Gözetimi Muhasebe ve Denetim Standartları (KGK) tarafından yayınlanan Finansal Raporlama Standartlarına Uygun yeni hesap taslağı baz alınarak hazırlanmıştır.

\section{TARIM İŞLETMELERİ}

Tarım işletmeleri genel tanımıyla tarımsal faaliyetlerle uğraşan işletmelerdir. Tarım işletmesi tarımsal ürünlerin üretilmesine yönelik olarak üretim faktörlerinin organizasyonunun oluşturduğu bütünlügün her bir parçasının ifade edilmesidir (Çetin ve Tipi, 2011: 18).

Tarımsal İşletme 7 Şubat 2019 tarih ve 30679 sayılı Resmi Gazetede yayınlanan Arazi Toplulaştırması ve Tarla İçi Geliştirme Hizmetleri Uygulama Yönetmeliğinde aşağıdaki gibi tanımlanmaktadır. Tarımsal İşletme: Yasal durumu ne olursa olsun, sahip olduğu, ortakçıllk, yarıcılık ya da kiralama şeklinde işlediği arazinin büyüklügüne bakılmaksızın kendi adına bitkisel üretim yapan ya da küçükbaş veya büyükbaş hayvan besleyen yahut hem bitkisel üretim hem hayvancilık yapan tek yönetim altındaki ekonomik birimi ifade etmektedir (Resmi Gazete, 2019).

Tarım işletmeleri;

* Tarımsal mahsul üretmesi: Sahip olduğu işletmede bitkisel ürün üretimi ya da hayvancilık yapması veya her iki üretimi aynı anda yapması,

* Ekonomik ve teknik olarak tek birim oluşması,

* Tek bir yönetime sahip olması: En az iki ya da iki kişiden fazla ortak tarafından müşterek olacak şekilde yürütülse dahi aralarında tek bir yönetimin var olması,

* Belirlenen kriterleri karşılaması veya kriterlerin altında olup da ürettiği tarımsal ürünlerden düzenli kazanç elde edebilecek satışlar yapması şeklinde ifade edilebilir. 


\subsection{Tarım İşletmelerinin Önemi}

Tarım işletmelerinin önemi ekonomik faktörler olarak bilinen doğa, sermaye, emek ve müteşebbis olmak üzere dört üretim faktörü oluşturmaktadır. İlk ekonomik faktör olarak sayılan doğa faktörünün temel yapı taşı özelliği konumundaki toprak tarımsal faaliyet sürecinin ana maddesini oluşturmaktadır. Tarımsal süreçte üretim durumunun büyük bir bölümü tarımsal işletmeler yoluyla gerçekleşmektedir. Tarım işletmelerinin ana koşulu olan üretim ve verim kaynağı topraktır. Toprak olmadan tarım ürünlerinin üretimini yapmanın imkânsız olması, tarıma elverişli arazilerin sınırlı olması ve kuraklık, erozyon gibi doğal sebeplerle tarım arazilerinin giderek azalmasından dolayı üretim miktarında yeterli şekilde artırıma gidilememesi sebebiyle toprak, sosyal yaşamın ilk gününden, içinde bulunduğumuz güne kadar gittikçe değer kazanan kaynakların başında gelmektedir. Bu sebeplerden dolayı tarım işletmeleri, temel unsuru olan toprağın üretim aşamasında önemli bir yere sahip olmasından dolayı önem arz etmektedir ( Bağatur, 1999:859).

\subsection{Türkiye' de Tarım İşletmeleri}

Türkiye'deki tarım işletmeleri hakkında 2016 yılında yapılan Tarımsal İşletme Yapı Araştırması (TIYA) ile tarımsal işletmelerin fiziksel büyüklüklerinin belirlenmesi, tarımsal işletmelerin tip ve ekonomik büyüklügü temel alınarak sınıflandırılması ve işletmelere ait temel yapısal istatistiklerin derlenmesi amaçlanmıştır. Araştırma sonuçlarına göre; Toplam işletmenin \%5,3'ü sadece büyükbaş ya da küçükbaş hayvan yetiştiriciliği yapmaktadır. Tasarrufunda arazi olan işletmelerin \%25,9'u 20-49 dekar işletme büyüklük grubunda yoğunlaşmakta, tarımsal işletmelerin tasarrufunda bulunan arazi ise \%24,5 ile en fazla 200-499 dekar işletme büyüklük grubunda yer almaktadır. Tarımsal işletmelerin \%80,7'si 100 dekardan küçük işletme büyüklük gruplarında yer almaktadır. Bu işletmelerin tasarrufunda bulundurduğu arazi ise toplam arazinin \%29,1'ini oluşturmaktadır (TÜİK, 2018).

Tarım faaliyetlerinde işletme şartları dikkate alınarak üretim planlamalarının yapılması, sınırlı sayıda olan üretim kaynaklarının dengeli düzeyde ve sağlıklı bir biçimde kullanılması tarımın değerini ve verimliliğini daha da ileri düzeye getirecektir (Erdoğan, 2004:1).

\subsection{Tarımsal Faaliyetlerin Ülke Ekonomisine Katkıları}

Tarım faaliyetlerinin ülke ekonomilerine olan katkısını inceleyen çalışmaların genelinde tarımın gelişmesi ile ekonomik gelişme arasında doğru orantılı bir ilişki tespit edilmiştir. Tarım sektörü ekonomik gelişme süresince genellikle diğer sektörlere oranla ekonomik gelişmeye daha az katkı sunmaktadır. Çünkü gelişmekte olan ülkelerin ekonomilerinde sanayi ve hizmet sektöründeki gelişmeler tarım sektöründeki gelişmelere oranla daha yüksektir. Tarım sektörü ülkemiz ekonomisi açısından büyük bir önem teşkil etmektedir. Ülke nüfusunun beslenmesini sağlaması, milli gelire ve istihdama katkı sağlaması, sanayi sektörünün hammadde ihtiyacını karşılaması, sanayiye sermaye aktarması, ihracat sektörüne doğrudan ve dolaylı katkıda bulunması gibi nedenlerle ekonomimizde vazgeçilmez bir sektör konumundadır (Doğan 2018:3). Türkiye' deki tarımın en önemli yapısal sorunu genellikle küçük ölçekli olmasıdır. Tarımsal üretimin ülke ekonomilerine katkıları ürün katkısı, üretim faktörü katkısı ve pazar katkısı şeklinde olmaktadır. Ürün katkısı, insan neslinin süreklilik arz etmesi için geçmişten günümüze kadar tarımsal ürünlerin üretiminin devamlı kılınmasıdır. Üretim faktörleri katkısı, emek, sermaye ve hammadde olarak sağlanmaktadır. Pazar katkısı ise, sektörün büyüyüp gelişmesi için üretilen ürünlerin satılmasıdır. Geçmiş dönemlerde tarım kaynaklı ekonomilere sahip olan gelişmiş ülkeler ilk olarak tarım sektörünün ilerlemesine daha çok kaynak sağlayarak tarım sektörünün gelişmesine katkı sunarak, tarım sektöründen elde edilen veriler sonucunda sanayi sektörünün ilerlemesine hız vermiştir. Almanya, Fransa, Japonya, Rusya ve İngiltere gibi gelişmiş ülkelerde 
sanayi sektörünün finansmanının büyük bir kısmı tarım sektöründen sağlanan girdilerle tedarik edilmektedir (Tuna 1993:42)

\subsection{Tarımsal İşletmelerde Muhasebe Sistemi ve Maliyetlendirme}

Tarımsal faaliyetlerde meydana gelen mali nitelikli işlemlerle ilgili kayıtların yapılması, yapılan kayıtların analiz edilmesi ve yorumlanması sonucunda, işletme yöneticilerine plan ve stratejileri belirleyebilmeleri için gerekli ve önemli bilgiler sağlanmaktadır. Sağlanan bilgilerin doğru olarak kullanılması, tarımsal faaliyetlerin vakit ilerledikçe ölçek olarak büyümesi ve daha çok teknolojik imkanların kullanımı nedenleriyle önem arz etmektedir.

Tarım muhasebesi sürecinin ilk amacı, işletmenin ekonomik ve fiziksel yapısı ile alakalı bilgi ve belgeler elde etmektir diyebiliriz. İşletme yöneticileri ya da işletme sahipleri, muhasebe biriminden elde edilen bilgi ve belgeleri, düzenli bir şekilde analiz ederek yorumladıktan sonra, işletmenin geleceğiyle alakalı daha faydalı kararlar alarak, alınan kararlar çerçevesinde yapılacak planlar ile strateji belirleyebilirler (Nergiz, 2013:145).

Tarımsal muhasebe, tarım işletmelerinin yapmış oldukları ekonomik nitelikteki faaliyet ve işlemleri kapsamaktadır. Tarımsal muhasebe, bilgileri kayıt altına alan, kayıt altına alınan bu verileri amacına uyumlu şekilde özetleyip gerekli analizleri yaparak bu verilerden yararlı bilgiler elde etmek amaciyla raporlayan, üretilen ürün ve mamullerin birim maliyetlerinin hesaplanmasına yardımcı olan bir muhasebe dalı olarak tanımlanmaktadır. Tarımsal işletmelerde maliyet değerleri genel olarak bölgelerin coğrafi konumlarına ve üretim yapan işletmelerin farklılıklarına göre değişim göstermesinden dolayı tarım alanında standart maliyet ya da kabul edilmiş maliyet verilerinden bahsetmek zordur. Bu alanda faaliyet gösteren işletmeler, kendi üretim şartlarına göre bir maliyet ve satış fiyatı hesaplamaktadırlar (Tokay ve Deran, 2011: 42).

Tekdüzen hesap planı taslağında daha önce 16. grupta yer alan Canlı varlıklar hesapları yayımlanan yeni finansal raporlama standartlarına uygun hesap planı taslağına göre 17. Grupta izlenmektedir(KGK 2018:22-25). Çalışmada finansal raporlama standartlarına uygun hesap planı taslağındaki hesap kodları kullanılmış olup tarım işletmeleri ile ilgili muhasebe kayıtları yeni hesap planı taslağına uygun şekilde yapılmıştır.

\section{TARIMSAL FAALIYETLER STANDARDI (TMS 41)}

TMS 412001 yılında Uluslararası Muhasebe Standartları Kuruluşu (IASB) tarafından yayınlanarak 1 Ocak 2003 yılında yürürlüğe girmiştir (Hatunoğlu ve Kıllı, 2016: 3). Ülkemizde tarım işletmelerinin muhasebe uygulamalarına yön vermek amacıyla ilk olarak Sermaye Piyasası Kurulu'nun 15 Kasım 2003 tarihindeki 25290 sayılı "Seri: XI, No: 25 Sermaye Piyasasında Muhasebe Standartları Hakkında Tebliğ" Resmi Gazete de yayınlanmıştır. Yayınlanan tebliğde 31. kısımda "Tarımsal Faaliyetler" başlığı altında borsaya kayıtlı tarım işletmelerinin faaliyetleri ile ilgili muhasebe düzenlemelerine yer verilmektedir. Tebliğin 31. kısmının genel amac1, tarımsal faaliyetlerle alakalı mali nitelikteki işlemlerin muhasebeleştirilmesi ve kamu sektörüne açılanmasına ilişkin kuralları belirlemektedir (Sönmez, 2004:143).

TMS 41 en genel anlamıyla tarımda meydana gelen faaliyetlerin ne şekilde muhasebe kayıtlarına alınması gerektiğini amaçlamaktadır. KGK tarafından yapılan açıklamada tarımsal faaliyet standardının genel amacı, tarımda meydana gelen faaliyetlerle ilgili muhasebe kayıt, yöntem ve açılama kısımlarını belirlemek şeklinde açıklanmıştır.

TMS 41'in kapsamına giren varlıklar şu şekildedir: 
$\Rightarrow$ Taşıyıcı bitkiler dışında kalan canlı varlıklar,

$\Rightarrow$ Hasat zamanında ortaya çıkan tarımsal mahsuller,

$\Rightarrow$ Devlet teşvikleri

Öte yandan tarımsal faaliyetlerle alakalı olmasına rağmen bu standardın dışında tutulan unsurlar ise şunlardır:

$\Rightarrow$ Tarımdaki faaliyetlerde meydana gelen taşıyıcı bitkiler

$\Rightarrow$ Tarımsal faaliyetlerle ilgili tarım arazileri

$\Rightarrow$ Taşıyıcı ürün ve bitkiler ile ilgili devlet teşvikleri

$\Rightarrow$ Tarımsal faaliyetle ilgili maddi olmayan duran varlıklar

$\Rightarrow$ Tarımsal faaliyetle ilgili olarak kiralanan arazilerden kaynaklanan kullanım hakkı varlıkları.

Tablo 1. TMS 41'in Kapsadığı Canlı Varlık Türleri ile Tarımsal Ürün ve Hasat Sonrası İşlem Diğer Ürünler

\begin{tabular}{|c|c|c|}
\hline Canlı Hayvanlar & Tarımsal Ürün & $\begin{array}{l}\text { Hasat Sürecinden Sonra } \\
\text { Elde Edilen Ürünler }\end{array}$ \\
\hline Koyun & Yün & Yün İpliği, Halı \\
\hline $\begin{array}{l}\text { Kerestelik Ağaç } \\
\text { Korusundaki Ağaçlar }\end{array}$ & Kütük & Kereste \\
\hline Mandıra Hayvanı & Süt & Peynir \\
\hline Sığır & $\begin{array}{l}\text { Gida Elde Edilmek Üzere } \\
\text { Kesilen Sığır }\end{array}$ & Sosis Pastırma \\
\hline Pamuk Bitkisi & Hasat Edilmiş Pamuk & İplik Giysi \\
\hline Şeker Kamışı & Hasat Edilmiş Kamış & Şeker \\
\hline Tütün Bitkileri & Toplanmış Yapraklar & İşlenmiş Tütün \\
\hline Çay Çalılığ & Toplanmış Yapraklar & Çay \\
\hline Üzüm Asmaları & Toplanmış Üzümler & Şarap \\
\hline Meyve Ağaçları & Toplanmış Meyveler & İleme alınmış Meyve \\
\hline Palmiye Ağaçları & Toplanmış Meyve & Palmiye Yağı \\
\hline Kauçuk Ağaçları & Hasat Edilmiş Lateks & Kauçuk Ürünler \\
\hline
\end{tabular}

Kaynak: TMS 41, prgf 4. 


\subsection{TMS 41'e Göre Muhasebeleştirme}

TMS 41' de işletmelerin canlı varlık ya da tarımsal bir ürününün muhasebeleştirilmesi için gerekli olan şartlar aşağıdaki gibi sıralanmaktadır (TMS 41, prgf.10):

$\checkmark$ Tarımla ilgilenen işletmenin, canlı varlık veya tarımsal ürünü geçmiş dönem olaylarının sonucu olarak kontrolü altında tutması,

$\checkmark$ Varlığa ilişkin gelecekteki ekonomik faydaların işletmeye aktarılmasının beklenmesi,

$\checkmark \quad$ Varlığın gerçeğe uygun değerinin veya maliyetinin güvenilir bir şekilde belirlenebilmesi.

Tarımsal faaliyetler açısından örneğin; sığırın yasal mülkiyeti ve edinim, doğum veya sütten kesilme sırasında damgalanması veya işaretlenmesi, canlı varlık üzerinde kontrolün bulunduğunun göstergesidir (TMS 41, prgf.11).

TMS 41'de, canlı varlık değerlerinin ölçümünün yapılması, muhasebeleştirme ve değerleme işlemleri, canlı varlıklarla alakalı olan kar zarar işlemleri, canlı varlıklarla ilgili amortisman uygulama işlemleri, tarımdaki faaliyetlerle alakalı devletin uyguladığı teşviklerin muhasebe kayıtları altına alınması ve finansal tablolara ait bilgilere yer verilmektedir. TMS 41, tarımda meydana gelen hasat aşamasını muhasebe işlemlerinde nokta olarak belirlemiş ve tarımsal varlıkların muhasebeleştirilmesi ve ölçülmesinde hasat noktası kriterine göre kurallar koymuştur (Hacıhasanoğlu ve Ünlü, 2017:396). Tablo 2'de hasat dönemi öncesi ve sonrasındaki olaylarla ilgili uygulanacak muhasebe standartları verilmiştir.

Tablo 2. Hasat Döneminden Önce ve Hasat Döneminden Sonra Ürünler İlgili Standartlar

\begin{tabular}{|c|c|c|}
\hline Hasattan önceki zaman & Hasat zamanı & Hasattan sonraki zaman \\
\cline { 3 - 3 } $\begin{array}{c}\text { Ürünün yetiştirilme ve } \\
\text { olgunlaşma zamanı }\end{array}$ & & Tarımsal ürün \\
\hline $\begin{array}{c}\text { Tarımsal Faaliyet Standardı } \\
\text { (TMS 41) }\end{array}$ & TMS 41 & $\begin{array}{c}\text { TMS 2 Stoklar veya ilgili } \\
\text { diğer standartlar }\end{array}$ \\
\hline
\end{tabular}

TMS 41 standardında yer alan canlı varlıklar tek düzen muhasebe sisteminde aşağıdaki kodlarla yer almaktadır:

Tablo 3. KGK Finansal Raporlama Standartlarına Uygun Hesap Planı Taslağına Göre Canlı Varlıklar Hesap Grupları

\begin{tabular}{|l|l|}
\hline 17. Canlı Varlıklar & 27. Canlı Varlıklar \\
\hline 170. Tarla Bitkileri & 270. Tarla Bitkileri \\
\hline 171. Bahçe Bitkileri & 271. Ağaçlar \\
\hline 172. Büyükbaş Hayvanlar & 272. Büyükbaş Hayvanlar \\
\hline 173. Küçükbaş Hayvanlar & 273. Küçükbaş Hayvanları \\
\hline 174. Kanatlı Hayvanlar & 274. Kanatlı Hayvanlar \\
\hline
\end{tabular}




\begin{tabular}{|l|l|}
\hline 175.Su Ürünleri Ve Diğer Canlı Varlıklar & 275. Su Ürünleri Ve Diğer Canlı Varlıklar \\
\hline 176. Canlı Varlıklar Değer Düş. Karş(-) & 276. Canlı Varlıklar Değer Düş. Karş(-) \\
\hline 177 & 277. Birikmiş Amortismanlar(-) \\
\hline 178 & 278. Yap. Olan Canlı Varlık Yat. \\
\hline 179. Verilen Sipariş Avansları & 279. Verilen Avanslar \\
\hline
\end{tabular}

Kaynak: KGK Finansal Raporlama Standartlarına Uygun Hesap Planı Taslağı.pdf, 2018.

Tarımsal faaliyet standardında canlı varlıklar ile tarımsal ürünler gerçeğe uygun değerleriyle ölçüldükten sonra maliyet değeriyle karşılaştırılırlar. Yapılan karşılaştırılma sonucunda meydana gelen artış veya azalışlar satış hâsılatıyla karşılaştırılarak gelir tablosunda gösterilir. Tarımsal faaliyetlerde meydana gelebilecek değerleme artışlarının 643- Tarımsal Faaliyetlerde Değerleme Artışları hesabında, değerleme azalışlarının ise 653- Tarımsal Faaliyetlerde Değerleme Azalışları hesabında izlenmesi öngörülmüştür.

\subsection{Tarımsal Faaliyetler}

Tarımsal faaliyet, satmak amacıyla bir canlı varlığın biyolojik değişme süreci sonucunda tarımsal ürün veya canlı varlığın bir parçası haline dönüşümünün bir işletme tarafından yürütülmesidir (Örten, Kaval, Karapınar, 2017:598). Diğer bir ifade ile tarımsal faaliyet, insan ihtiyacını karşılamak amacıyla üretim faktörlerinden yararlanılarak hayvan ve bitkisel ürünler üreterek bu üretimden elde edilen ürünleri mamul ve yarı mamul şekline dönüştürme faaliyetleridir (Abakay, 2019:7).

TMS 41'de yapılan tarımsal faaliyetin açıklamaları ve tanımlanması diğer yerlerdeki tanım ve açıklamalara göre dar ve kapalı bir şekilde tanımlanmıştır. Tarımsal faaliyetler standardı kuralına göre tarımsal ürün şartını sağlamak için tarımla alakalı faaliyet göstermek gereklidir. Bu şartı sağlayan varlıklar (TMS 41, md.1);

$>$ Taşıyıcı bitkiler hariç canlı varlıklar,

$>$ Hasat zamanındaki tarımsal ürünler,

$>$ Devlet teşvikleridir.

TMS 41'e göre herhangi bir işletmenin açıklanan varlıkları elde etmesi ya da bu varlıklara sahip olması esnasında muhasebe kayıtlarını ve değerleme işlemlerini TMS 41 'de belirtilen esaslara göre yapması gereklidir.

\section{BİR SERA DOMATESI FİRMASINDA ÖRNEK OLAY ÇALIŞMASI}

\section{1. Çalışmanın Amacı ve Önemi}

Günümüzde ekonomik gelişmeler sebebiyle tarım sektörüne olan ilgi gün geçtikçe artmaktadır. $\mathrm{Bu}$ ekonomik gelişmeler sonucunda tarım sektöründe makineleşmenin giderek artmasından dolayı, tarım sektöründe faaliyet göstermek daha da kolay bir hal almıştır. Ekonomik gelişmelerden kaynaklı olarak tarım sektörüne olan ilgi ile birlikte tarımsal muhasebenin önemi daha da artmıştır.

Bu çalışmanın amacı domates üreten bir işletmenin gerçek verilerini kullanarak Tarımsal faaliyet standardına göre yapması gerekli muhasebe kayıtlarını göstermektir. Çalışmada Van ilinde 
domates üretimini gerçekleştiren $X$ sera işletmesinin gerçek mali verileri alınarak TMS 41 tarafından belirtilen muhasebe kayıtları ile maliyet hesaplamaları yapılmıştır. Yapılan muhasebe ve maliyet hesaplama kayıtları KGK finansal raporlama standartlarına uygun yeni tekdüzen hesap planı taslağına göre yapılmıştır.

\section{2. Çalışmada Kullanılan Veriler}

Örnek olay çalışmasının yapıldığı X işletmesi 2014 yılında Van ilinin Çaldıran ilçesinin 3 km güneyinde Çaldıran jeotermal sahası içinde 34 dekarlık alanda kurulmuştur. İşletmenin üretimini gerçekleştirdiği domates seraları 5 metre oluk altı, çelik konstrüksiyonu galvanizli çelik olup yan duvarları $8 \mathrm{~mm}$ kalınlığında şeffaf polikarbondan yapılmıştır. Sera örtüsü olarak da 4 mikronluk özel alaşımlı naylondan yapılmıştır.

Çaldıran jeotermal havzası, merkezi 1sıtma, seracılık, termal turizm ve hatta elektrik enerjisi üretimi projelerine cevap verebilecek düzeyde yüksek potansiyele sahiptir.

Araştırmaya konu olan $X$ işletmesi serasında domates üretimi yapılmaktadır. Sera işletmesinden alınan bilgiye göre domates üretimi için en önemli kriterlerden biri ilk madde malzeme olarak domates fidelerinin temin edilmesidir. İşletme fidelerini Ege ya da Akdeniz bölgesinde temin etmektedir. Alınan bu fideler yıllık olarak üretimde kullanılmaktadır. Fidelerin en önemli özelliği salkım domatesler elde edilmesidir. Salkım domatesler tarla domateslerinden farklı olarak 5 adet şeklinde birbirine bağlı olarak yeşermektedir. Alınan fideler insan gücüyle dikilip daha sonra gerekli ilaçlama, gübreleme gibi bakımlar yapılarak domates üretimi gerçekleşmektedir. Domates seralarının en önemli ilk madde malzeme giderlerinden birisi de sulama gideridir. Bölgenin konumu itibari ile kış mevsiminde -40 dereceye kadar düşebilen hava şartlarında sera ortamının sıcak tutularak üretimin yapılması gereklidir. Bu da jeotermal kaynağı sonucunda açlan sıcak su kuyularıyla seranın iç bölgesine verilen sulama sistemiyle üretim yapılmasına olanak sağlamaktadır. Bunun sonucunda sera ortam sıcaklığı +15 derecelerde tutularak kış aylarında domates üretimi devam etmektedir. Sulama dayanıklı sıcak su borularıyla yapılmaktadır. Bu şekilde yapılan isıtma sonucunda daha doğal domates ürünü elde edilmektedir. Sulama gideri işletmeye yıllık olarak yansımaktadır. İşletmede yıllık olarak gerçekleşen ilk madde malzeme giderleri Tablo 4 'te gösterildiği gibidir.

Tablo 4. X İşletmesi İlk Madde ve Malzeme Gideri

\begin{tabular}{|c|l|r|}
\hline 1 & Fideler & $350.000,00$ \\
\hline 2 & Sulama giderleri (1sıtma boruları vb.) & $249.500,46$ \\
\hline 3 & Gübreler & $286.354,00$ \\
\hline 4 & İlaçlar & $28.933,00$ \\
\hline TOPLAM (1+2+3+4) & Direkt İlk Madde ve Malzeme Gideri & $\mathbf{9 1 4 . 7 8 7 , 4 6}$ \\
\hline 5 & Endirekt İlk Madde ve Malzeme Gideri & $\mathbf{4 8 . 0 0 7 , 0 0}$ \\
\hline TOPLAM (1+2+3+4+5) & İlk Madde Malzeme Giderleri Toplamı & $\mathbf{9 6 2 . 7 9 4 , 4 6}$ \\
\hline
\end{tabular}

Domates üretimi yapan sera işletmesinde üretimin yapılabilmesi için hem idari hem de fiziki iş gücüne ihtiyaç vardır. Sera işletmelerinde domates üretiminde kaliteli üretim elde edilmesi için kontrol mühendisleri ve üretim esnasında makineleri kullanabilen kalifiyeli personellere ihtiyaç duyulmaktadır. İşletme tarafından dışarıdan temin edilen domates fidelerinin dikiminde, 
domateslerin hasat edilmesinde ve satış sürecine insan gücüne ihtiyaç duyulmaktadır. Sera işletmesinde çalışan personellerin büyük bir kısmını kadın personeller oluşturmaktadır. Bu da bölgede kadın çalışanların oranının yükselmesine etki etmektedir. Tablo 4'de gösterildiği gibi fidelerin dikimi, domatesin hasat edilmesi, fidelerin budaması gibi işçilikler belli bir üretim aşamasında ve yönetimin belirlediği planlama çerçevesinde gerçekleşmektedir. Üretim sürecinde kontrol genellikle ziraat mühendisleri tarafından yapılmaktadır. Kaliteli ürün elde edilmesi için önemli koşullardan biri de işçiliğin titizlikle ve kontrollü bir şekilde yapılmasıdır. İşletmede yıllık olarak gerçekleşen direkt ve endirekt işçilik gideri Tablo 5'de detaylandırılmıştır.

Tablo 5. X İşletmesi İşçi Ücret ve Giderleri

\begin{tabular}{|c|l|r|}
\hline & Direkt İşçi Ücret ve Giderleri \\
\hline 1 & Fidan dikimi işçiliği & $\mathbf{1 2 9 . 9 1 1 , 3 0}$ \\
\hline 2 & Hasat işçiliği & $\mathbf{1 1 . 4 5 0 , 0 4}$ \\
\hline 3 & Kök ve gövde temizliği işçiliği & $\mathbf{3 6 . 7 0 0 , 0 0}$ \\
\hline 4 & Sulama sistemi işçiliği & $\mathbf{5 6 . 3 0 0 , 0 0}$ \\
\hline 5 & Bitki koruma işçiliği & $\mathbf{2 2 . 2 5 0 , 0 0}$ \\
\hline 6 & Budama işçiliği & $\mathbf{2 . 4 2 0 , 5 0}$ \\
\hline 7 & Gübreleme işçiliği & $\mathbf{5 2 . 1 5 0 , 0 0}$ \\
\hline 8 & İlaçlama işçiliği & $\mathbf{4 7 . 2 5 0 , 0 0}$ \\
\hline 9 & Direkt İşçilik Giderleri Toplamı & $358.431,84$ \\
\hline Toplam(1+2+3+4+5+6+7+8) & $\mathbf{7 3 . 4 7 8 , 2 6}$ \\
\hline Toplam(1+2+3+4+5+6+7+8+9) & İşçi Ücret ve Giderleri Toplamı & $\mathbf{4 3 1 . 9 1 0 , 1 0}$ \\
\hline
\end{tabular}

İşletme tarafından üretimi yapılan domates seralarında yılın 8 ayında üretim, 4 ayında da fide ve makine bakımları yapılmaktadır. Üretim sürecinde her işletme de olduğu gibi bir takım üretim giderlerine katlanılmaktadır. Genel üretim giderleri, üretimin yapılması için gerekli elektrik giderleri, domatesin doğal üretimi için kullanılacak arılar ve bakım yapılması için gerekli malzeme giderlerinden oluşmaktadır. Seralarda doğal üretim gerçekleşmektedir. Hormon ya da benzeri sentetik ürünlerin kullanımı gerekli olmadıkça minimum seviyelerde olmaktadır. Biyolojik mücadele şeklinde üretim yapılıp zararlı böceklere karşı avcı böcekler kullanılmaktadır. Bu şekilde avcı böceklerin kullanılması ilaç kullanımını düşürmektedir. Bu şekilde domates üretimi daha doğal ortamda gerçekleşebilmektedir. Bitkinin üretileceği ortam ile bitkiye katkı sağlayacak arılar üretim esnasında kullanılmaktadır. Ayrıca üretim esnasında dikilen fidelerin sağlıklı yeşerebilmesi amacıyla askı ipi vb. çeşitli ürünlere ihtiyaç duyulmaktadır. İşletmede gerçekleşen üretim giderleri Tablo 6' da açıklanmıştır. 
Tablo 6. X İşletmesi Genel Üretim Giderleri

\begin{tabular}{|r|l|r|}
\hline & Genel Üretim Giderleri \\
\hline 1 & Memur ücret ve giderleri & $\mathbf{7 . 1 6 8 , 8 8}$ \\
\hline 2 & Çeşitli giderler & $\mathbf{1 7 . 5 2 1 , 7 6}$ \\
\hline 3 & Amortisman ve tükenme payları & $\mathbf{5 0 . 8 1 3 , 2 1}$ \\
\hline 4 & Elektrik kullanımı & $\mathbf{2 0 6 . 9 0 8 , 8 2}$ \\
\hline \multirow{2}{*}{4} & Genel Üretim Giderleri Toplamı & $\mathbf{2 8 2 . 4 1 2 , 6 7}$ \\
\cline { 2 - 3 } & &
\end{tabular}

Domates üretimi yapan sera işletmesinin yıllık olarak katlandığı üretim değerleri tablolarda yer almaktadır. Bir ürünün elde edilmesi amacıyla öncelikle yetiştirilecek ürünün fidelerinin olması gerekmektedir. Üretime, fidenin büyümesi için ihtiyaç duyduğu su, gübre ve tozlaşma(üreme) için gereken bambus arıları ile başlanmaktadır. Aynı şekilde bitkinin sağlıklı ve daha verimli bir şekilde büyümesi için kültürel işlemler de belli aralıklarla yapılarak bitki gelişimine destekte bulunulmaktadır. Üretim esnasında sera alanı sıcak su sistemiyle 1sıtılmaktadır. Jeotermal ssıtma sistemi ile isıtılan seralar diğer 1sıtma sistemiyle ssıtılan seralara göre maliyet açısından avantajlıdır. Bölgenin sera yatırımına olan cazibesi de ısıtma sisteminin maliyet açısından daha düşük olmasıdır. Yine de ısıtma sistemi şirketlere ek bir gider olarak yansımaktadır. Bu veriler 1şı̆̆ında işletme gelecek dönemlerin üretim giderlerini tahmini olarak hesaplayabilmektedir.

\subsection{TMS 41'e Göre Tarımsal Faaliyet İşlemlerinin Muhasebeleştirilmesi}

Tarımsal faaliyet standardına uygun olarak yapılması gerekli muhasebe kayıtları KGK tarafından hazırlanan yeni tek düzene uygun şekilde yapılmıştır. Literatürde tarım muhasebesi ile ilgili çalışmalarda maliyetlerin izlenmesinde muhasebe kayıtlarını 7/A seçeneğini kullanarak yapan çalışmalar bulunmakla birlikte 7/B seçeneği maliyet hesaplarının tarım işletmelerine ve TMS 41' in genel felsefesine daha uygun olduğu görüşünü benimseyen çalışmalarda mevcuttur (Aksoylu, 2013: 71; Kıllı, 2014:83). Bu çalışmada, tarımsal faaliyetler ile ilgili maliyetlerin kayda alınmasında giderlerin çeşitlerine göre izlenmesi yaklaşımı olan 7/B seçeneği kullanılmıştır.

\subsubsection{Domates Alanının Hazırlanması, Fide Dikimi ve Üretim Maliyetleri Muhasebe Kayitları}

İşletme Ocak, Temmuz ve Ağustos aylarında ekim, diğer aylarda ise hasat yapmaktadır. Ekim işlemlerinden sonra hasada kadar geçen süre ortalama 70 gündür ve hasat yaklaşık 80-90 gün kadar devam etmektedir. Dolayısı ile Ocak ayının başında ekilen domatesin hasadı Mart ayının ortası ile Mayıs ayının sonlarına; Haziran ayının başında ekilen domateslerin hasadı Ağustos ayının ortası ile Ekim ayının sonlarına ve Temmuz ayında ekilen domateslerin hasadı ise Eylül ayının ortalarından Aralık ayının ortalarına kadar sürebilmektedir. Tablo 4, 5 ve 6'da görüldüğü gibi domates ekim faaliyetlerine ait gider toplamı 1.677.117,23 TL'dir. Domates ekiminden hasadına kadar geçen sürede ortaya çıan bu giderlerin 7/B maliyet seçeneğine göre muhasebe kayıtları aşağıdaki gibi olacaktır. 


\begin{tabular}{|c|c|c|}
\hline \multirow[t]{2}{*}{ 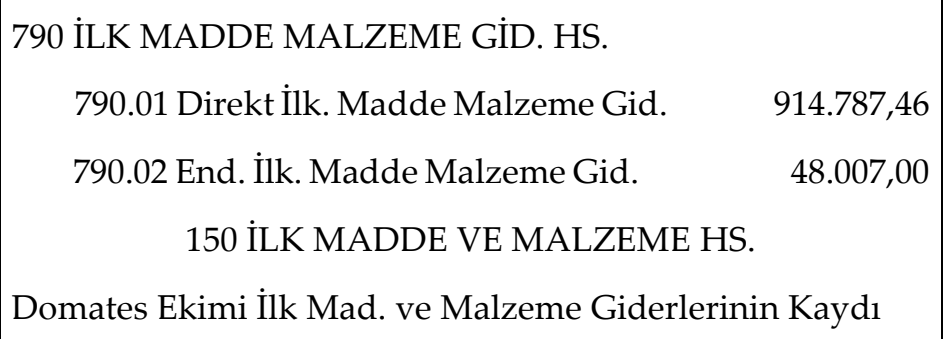 } & \multirow[t]{2}{*}{$962.794,46$} & \multirow[t]{2}{*}{$962.794,46$} \\
\hline & & \\
\hline 791 İŞÇİ ÜCRET VE GİDERLERİ & $431.910,10$ & \\
\hline 791.01 Direkt İşçilik Gid. & & \\
\hline 791.02 Endirekt İşçilik Gid. & & \\
\hline 792 MEMUR ÜCRET VE GIDDERLERİ & $7.168,88$ & \\
\hline 793 DIŞARDAN SAĞ. FAYDA VE HİZMETLER & $206.908,82$ & \\
\hline 794 ÇEŞITLII GIDERLER & $17.521,76$ & \\
\hline 796 AMORTISMANLAR VE TÜKENME PAYLARI & $50.813,21$ & \\
\hline 102 BANKALAR HS. & & \\
\hline 257 BİRIKMIŞ AMORTİSMANLAR HS. & & $663.509,56$ \\
\hline $\begin{array}{l}\text { İşçi Ücret Giderlerinin Banka Hesabından Ödenmesi ve } \\
\text { Amortisman Payının Ayrılması Kaydı }\end{array}$ & & $50.813,21$ \\
\hline
\end{tabular}

Hasat dönemine ait üretim maliyetlerinin ilgili maliyet hesaplarına kaydedilmesinden sonra yansıtma hesapları aracılığıyla üretim maliyet hesabına aktarılmasına ilişkin muhasebe kayıtları aşağıda verilmiştir.

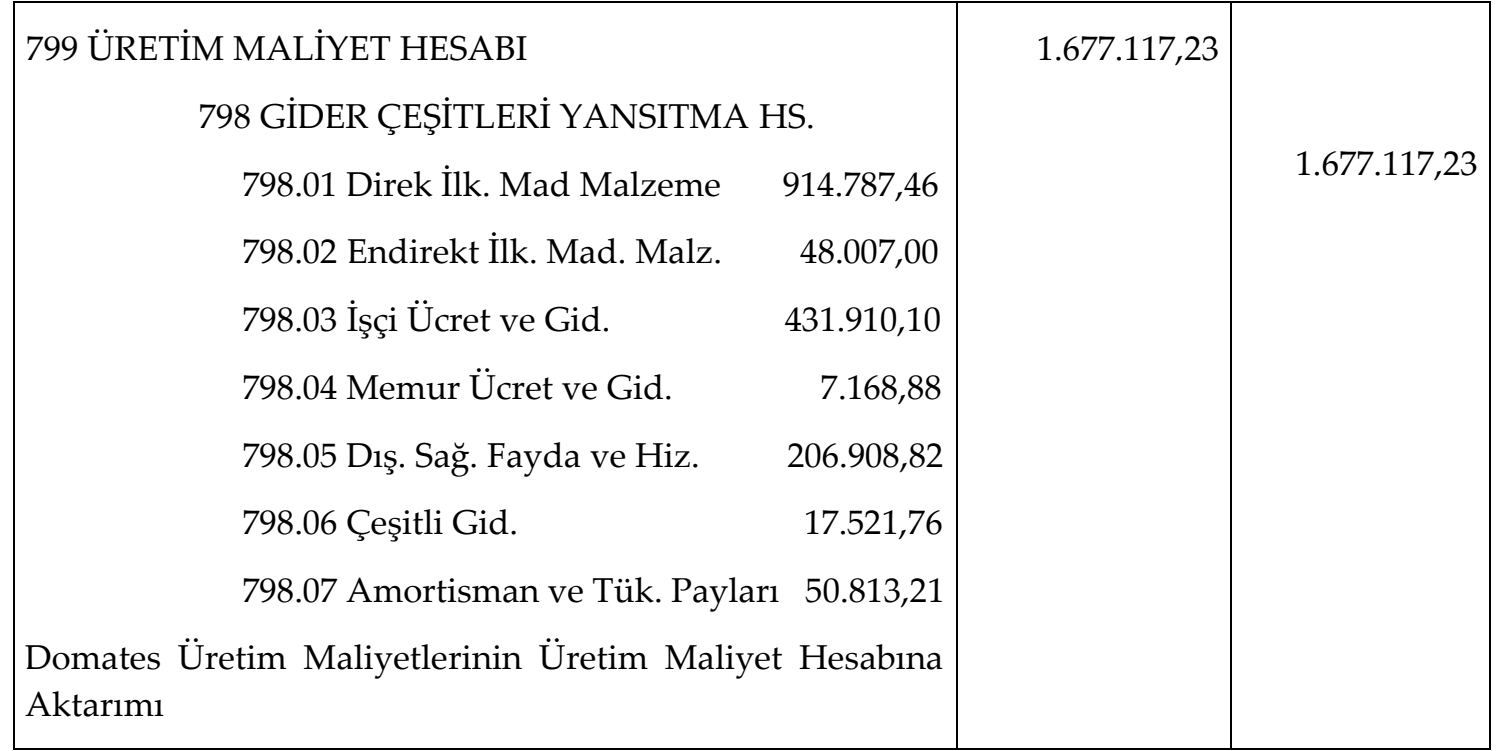




\begin{tabular}{|c|c|c|}
\hline 798 GİDER ÇEŞITTLERİ YANSITMA HESAPLARI & \multirow[t]{19}{*}{$1.677 .117,23$} & \\
\hline 798.01 Direk İlk. Mad Malzeme & & \\
\hline 798.02 Endirekt İlk. Mad. Malzeme & & \\
\hline 798.03 İşçi Ücret ve Gid. & & \\
\hline 798.04 Memur Ücret ve Gid. & & \\
\hline 798.05 Diş. Sağ. Fayda ve Hiz. & & \\
\hline 798.06 Çeşitli Gid. & & \\
\hline 798.07 Amortisman ve Tük. Payları & & \\
\hline 790 İLK MADDE VE MALZEME GIDERLERİ & & \\
\hline 790.01 Direk İlk. Mad Malzeme & & $962.794,46$ \\
\hline 790.02 Endirekt İlk. Mad. Malzeme $\quad 48.007,00$ & & \\
\hline 791 İŞÇİ ÜCRET VE GİDERLERİ & & \\
\hline 791.01 Direkt İşçilik Gid. & & $431.913,10$ \\
\hline 791.02 Endirekt İşçilik Gid. & & \\
\hline 792 MEMUR ÜCRET VE GİDERLERİ & & \\
\hline 793 DIŞ. SAĞLANAN FAYDA VE HIZZMETLER & & $7.168,88$ \\
\hline 794 ÇEŞİTLİ GİDERLER & & $206.908,82$ \\
\hline 796 AMORT. VE TÜKENME PAYLARI & & $17.521,76$ \\
\hline Maliyet ve Yansıtma Hesaplarının kapatılması & & $50.813,21$ \\
\hline
\end{tabular}

Domates fidelerinin ekiminden sonra domates bitkisindeki biyolojik dönüşüm gerçeğe uygun değer ile ölçülmesi için yeterli değildir. Domates fidelerinin ilk maliyetlerinin yüklenmesinden sonra çok az bir biyolojik dönüşüm gerçekleştiğinden maliyet gerçeğe uygun değere yakındır (TMS 41, Prgf 24). Bu nedenle domates fidelerinin ekim maliyetlerinin 799 Üretim Maliyet Hesabına yansıtılmasından sonra 171 Bahçe Bitkileri hesabında izlenmesi gerekir.

\begin{tabular}{|l|r|r|}
\hline $\begin{array}{l}\text { 171 BAHÇE BITKKILERİ } \\
\text { 171.01 Sera Domatesi } \\
\text { 799 ÜRETIM MALIYYT HESABI }\end{array}$ & $1.677 .117,23$ & \\
$\begin{array}{l}\text { Ekim maliyetlerinin Üretim maliyet Hesabından Bahçe } \\
\text { Bitkileri hesabına aktarımı }\end{array}$ & & $1.677 .117,23$ \\
\hline
\end{tabular}

\subsubsection{Domates Ürünün Dönem Sonu Gerçeğe Uygun Değerinin Hesaplanması Ve Muhasebeleştirilmesi}

Tarımsal ürün ve canlı varlıkların gerçeğe uygun değerinin hesaplanmasında yapılacak ilk adım, canlı varlıkların ve tarımsal ürünlerin faaliyet gösteren piyasasının bulunup bulunmamasına göre değişiklik göstermektedir. Üretilen domates ürünün piyasa fiyatı, piyasada mevcut son fiyat 
ile hasat edilen domatesin çarpımı sonucunda bulunmaktadır. Aralık ayı hasat sürecinin tamamlandığı ay olduğu için piyasa fiyatı olarak 3,61 TL alınmıştır.

Piyasa Fiyatı= Piyasadaki Son Fiyat ${ }^{*}$ Domates Hasad 1

Piyasa fiyatı $=3,61 \mathrm{TL} * 487500 \mathrm{KG}$

Piyasa fiyatı $=1.759 .875 \mathrm{TL}$

Araştırmaya konu olan domates işletmesi yerinde satış politikası izlemesinden dolayı pazara getirme maliyetleri sıfırdır. İşletmenin üretmiş olduğu domates herhangi bir pazar sahasına götürülmemektedir. Bir başka ifade ile üretimi gerçekleştirilen domates ürünü kasalara konulduktan sonra alıcı işletmeler tarafından kendi imkânlarıyla ürün pazar sahasına götürülmektedir. Bu şekilde üretici işletme tarafından herhangi bir şekilde pazara götürme maliyeti, sigorta, nakliye vb. giderler yapılmamaktadır.

Canlı varlığın gerçeğe uygun değeri = piyasa fiyatı- pazara getirme maliyetleri

Canlı varlığın gerçeğe uygun değeri= 1.759 .875 - 0

Canlı varlığın gerçeğe uygun değeri= $\mathbf{1 . 7 5 9 . 8 7 5 , 0 0 ~ o l a r a k ~ h e s a p l a n m ı s ̧ t ı r . ~}$

Canlı varlığın değer artış/azalış= canlı varlı̆̆ın gerçeğe uygun değeri-satılan mamul maliyeti

Canlı varlığın değer artış/azalış $=1.759 .875,00-1.677 .117,23$

Canlı varlığın değer artış/azalış $=82.757,77$ TL olarak artış şeklinde hesaplanmıştır

İşletmede gerçeğe uygun değerin üretim maliyetinden yüksek olması sonucunda tarımsal üründe değer artışı meydana gelmiş ve buna uygun yevmiye kaydı yapılmıştır.

\begin{tabular}{|l|r|r|}
\hline $\begin{array}{l}\text { 171 BAHÇE BİTKİLERI } \\
\text { 643 TARIMSAL FAALIYYETLERDE DEĞ.ARTIŞLARI }\end{array}$ & $82.757,77$ & \\
Gerçeğe Uygun Değer Artışının Kaydı & & $82.757,77$ \\
\hline
\end{tabular}

TMS 41'de canlı varlıklardan elde edilen tarımsal ürünlerin, hasat noktasında, gerçeğe uygun değerlerinden satış maliyetleri düşülerek ölçülmesi gerektiği ifade edilmektedir. İşletmemizde yukarıda da ifade edildiği gibi satış maliyeti bulunmadığından hasat noktasında 171 Bahçe Bitkileri hesabından 152 Mamuller hesabına aktarılan tutar stok maliyeti olacaktır.

\begin{tabular}{|l|l|l|}
\hline 152 MAMULLER & $1.759 .875,00$ & \\
171 BAHÇE BİTKİERİ & & $1.759 .875,00$ \\
$\begin{array}{l}\text { Domateslerin hasat noktasında Bahçe Bitkileri hesabından } \\
\text { Mamul stoklarına aktarılması }\end{array}$ & & \\
\hline
\end{tabular}

\subsubsection{Domates Hasadı ve Satışı}

Mevsimsel şartların zor olduğu Doğu Anadolu bölgesinde sera domateslerinin tarla domateslerine göre en büyük avantajı kış aylarında da üretiminin yapılabilmesidir. Çünkü kış aylarında yoğun kar yağışı ve kış mevsiminin uzun sürmesi sebebiyle tarla domatesi üretimi yapılamamaktadır. Ancak seralarda üretilen domatesler gerekli ısı sistemi ve fide ekimi istenilen mevsimde yapıldığı için üretim kış aylarında da yapılmaktadır. Üretimi kış aylarında yapılan domatesin en önemli etkilerinden biri fiyat farkının fazla olmasıdır. Çünkü kışın tarla domatesin sevkiyatı fazla olamadığından sera domateslerinin fiyatı daha fazla olmaktadır. Hasat dönemi 
domatesin olgunlaşarak satışa sunulması amacıyla fidelerden koparılma sürecidir. Domatesler, her salkımda beş adet domates olacak şekilde kasalara yerleştirilmektedir. Ayrıca her salkım ortalama $0,5 \mathrm{~kg}$ ağırlığındadır. Hasat işlemine ait giderler daha önceki bölümlerde verildiğinden ve kaydı yapıldığından bu bölümde ayrıca gösterilmemiştir.

Tablo 7. Domates Hasat Aylara Göre Dağılımı

\begin{tabular}{|c|c|c|c|c|c|c|}
\hline Aylar & $\begin{array}{l}\text { Salkım } \\
\text { sayisı } \\
\text { (A) }\end{array}$ & $\begin{array}{l}\text { Salkım } \\
\text { ağırlığ1 } \\
\text { (kg) } \\
\text { (B) }\end{array}$ & $\begin{array}{l}\text { Metre } \\
\text { kareye } \\
\text { düssen } \\
\text { bitki sayısı } \\
\text { (C) }\end{array}$ & $\begin{array}{l}\text { Toplam } \\
\text { bitki sayısı } \\
\text { (D) }\end{array}$ & $\begin{array}{l}\text { Bitkide } \\
\text { ürün } \\
\text { miktarı } \\
(\mathrm{kg}) \\
(\mathrm{E})=\mathrm{A}^{*} \mathrm{~B}\end{array}$ & $\begin{array}{l}\text { Toplam } \\
\text { ürün } \\
\text { miktarı }(\mathrm{kg}) \\
(\mathrm{F})=\mathrm{E}^{*} \mathrm{D}\end{array}$ \\
\hline \multicolumn{7}{|l|}{ Ocak } \\
\hline \multicolumn{7}{|l|}{ Şubat } \\
\hline Mart & 5 & 0,5 & 2,4 & 15.000 & 2,5 & 37.500 \\
\hline Nisan & 5 & 0,5 & 2,4 & 20.000 & 2,5 & 50.000 \\
\hline Mayıs & 5 & 0,5 & 2,4 & 20.000 & 2,5 & 50.000 \\
\hline \multicolumn{7}{|l|}{ Haziran } \\
\hline \multicolumn{7}{|c|}{ Temmuz } \\
\hline Ağustos & 5 & 0,5 & 2,4 & 15.000 & 2,5 & 37.500 \\
\hline Eylül & 5 & 0,5 & 2,4 & 20.000 & 2,5 & 50.000 \\
\hline Ekim & 5 & 0,5 & 2,4 & 50.000 & 2,5 & 125.000 \\
\hline Kasım & 5 & 0,5 & 2,4 & 40.000 & 2,5 & 100.000 \\
\hline Aralık & 5 & 0,5 & 2,4 & 15.000 & 2,5 & 37.500 \\
\hline & & & & & & $\begin{array}{l}\text { PLAM: } \\
\qquad 87.500\end{array}$ \\
\hline
\end{tabular}

Domates üretimi yapan işletme yılın belli aylarında belirli tutarda domates üretimini gerçekleştirmektedir. Daha çok üretimin elde edilmesinde dikilen bitki sayısı etkilidir. İşletme ocak, şubat, haziran, temmuz aylarında fide dikimine gittiği için üretim mevcut değildir. Tabloda da görüldüğü gibi işletme kış üretimi yapmaktadır. Kış aylarında gerekli ısıtma şartlarının jeotermal suyu tarafından sağlanması sonucu üretim gerçekleşmektedir. 
Tablo 8. Domates Satış Geliri

\begin{tabular}{|l|c|l|l|}
\hline Aylar & $\begin{array}{l}\text { Üretilen domates } \\
\text { miktarı (A) }\end{array}$ & $\begin{array}{l}\text { Piyasa satış fiyatı } \\
\text { (B) }\end{array}$ & $\begin{array}{l}\text { Elde edilen gelir } \\
\text { C=A*B }\end{array}$ \\
\hline Ocak & & & $206.250,00 \mathrm{TL}$ \\
\hline Şubat & 37.500 & $5,50 \mathrm{TL}$ & $412.500,00 \mathrm{TL}$ \\
\hline Mart & 50.000 & $5,50 \mathrm{TL}$ & $375.000,00 \mathrm{TL}$ \\
\hline Nisan & 50.000 & $5,00 \mathrm{TL}$ & \\
\hline Mayıs & & & $150.000,00 \mathrm{TL}$ \\
\hline Haziran & 37.500 & $4,00 \mathrm{TL}$ & $365.625,00 \mathrm{TL}$ \\
\hline Temmuz & 112.500 & $3,25 \mathrm{TL}$ & $285.000,00 \mathrm{TL}$ \\
\hline Ağustos & 125.000 & $2,28 \mathrm{TL}$ & $250.500,00 \mathrm{TL}$ \\
\hline Eylül & 100.000 & $3,34 \mathrm{TL}$ & $135.375,00 \mathrm{TL}$ \\
\hline Ekim & 37.500 & $3,61 \mathrm{TL}$ & \\
\hline Kasım & TOPLAM & & \\
\hline Aralık & & & \\
\hline & & & \\
\hline
\end{tabular}

İşletmenin yıllık olarak üretip sattığı miktarlar ve tutarlar Tablo 8 ‘de gösterilmektedir. Tablo incelendiğinde fiyatların aylara göre farklılık gösterdiği görülmektedir. Bunun sebebi mevsimsel olarak dışarıdan gelen domates ve mevsimsel şartlardır. Kış aylarında özellikle tarla domatesin olmaması sebebiyle fiyatlar artarken yaz ayarlında tarladan gelen domatesin piyasaya girmesiyle beraber fiyatlar düşmektedir. Ocak, Şubat, Haziran, Temmuz aylarında işletme satış ve üretim yapmamaktadır. Bu aylarda işletme genellikle planlanan bakım onarım çalışmaları nedeniyle domates üretimi gerçekleştirmemektedir. Domates satış fiyatının yıllık ortalama değeri, yıllık toplam satışların (TL) yıllık üretim miktarına $(\mathrm{kg})$ bölünmesi ile elde edilecektir;

$$
\text { Yıllık Ortalama Satış Fiyatı }=\frac{\text { Yıllık Toplam Satışlar }}{\text { Yıllık üretim miktarı }}
$$

$$
\begin{gathered}
\text { Yıllık Ortalama Satış Fiyatı }=\frac{2.180 .250}{487.500} \\
\text { Yıllık Ortalama Satış Fiyatı }=4,47 \mathrm{TL}
\end{gathered}
$$

Bütün aylardaki satışları toplayıp yıllık olarak üretilen ürün miktarına böldügüumüzde yıllık ortalama satış fiyatı hesaplanabilmektedir. Hesaplamalarda yıllık olarak işletmenin domates satış 
fiyatı 4,47 TL olarak hesaplanmıştır. Domates satış kayıtlarında KDV hesaplaması ihmal edilmiştir.

Domates satış hasılatı: $2.180 .250,00$

Domatesin satış geliri: $2.180 .250,00-1.759 .875,00=420.375,00$

\begin{tabular}{|l|l|l|}
\hline $\begin{array}{l}\text { 102 BANKALAR } \\
\text { Domates Satış Kaydı } 1\end{array}$ & $2.180 .250,00$ & \\
\hline $\begin{array}{l}\text { 620 SATILAN MAMUÇİ SATIŞLAR } \\
\text { 152 MAMULLER } \\
\text { Satışı yapılan domateslerin maliyet kaydı }\end{array}$ & $1.759 .875,00$ & $2.180 .250,00$ \\
\hline
\end{tabular}

\subsubsection{Dönem Sonu Kayıtları}

Dönem sonunda domates üretim faaliyetlerinden ortaya çıkan edilen gelir ve gider hesapları önce 690 Sürdürülen Faaliyetler Dönem Karı veya Zararı hesabına aktarılır, daha sonra vergi karşılığı ayrılır. Vergi karşılığı ayrılması sonrası 690 ve 691 kapatılarak 693 no'lu hesaba aktarılır. Bu işlemlerden sonra 693 Sürdürülen Faaliyetler Dönem Net Karı Veya Zararı Hesabı kapatılarak 699 Dönem Net Karı Veya Zararı Hesabına aktarılır. Kar/zarar olması durumlarına göre 590 veya 591 no'lu hesaplardan birine aktarılır.

\begin{tabular}{|c|c|c|}
\hline $\begin{array}{l}600 \text { YURTİ̧İ SATIŞLAR } \\
643 \text { TARIMSAL FAALIYETLERDE DEĞERLEME ARTIŞLARI } \\
\qquad 690 \text { SÜRDÜRÜLEN FAAL. DÖN. KARI VEYA ZAR } \\
\text { Yurtiçi Satışların Ve Tarımsal Faaliyetlerde Değerleme Artışının } \\
\text { Dönem Kar Zararına Aktarılması Kaydı }\end{array}$ & $\begin{array}{r}2.180 .250,00 \\
82.757,77\end{array}$ & $2.263 .007,77$ \\
\hline $\begin{array}{l}690 \text { SÜRDÜRÜLEN FAALIYETLER DÖN.KARI VEYA ZAR. } \\
\qquad 620 \text { SATILAN MAMULLER MALIYETI } \\
\text { Satılan Mamul Maliyetinin Kar Zarar Hesabına Aktarılması }\end{array}$ & $1.759 .875,00$ & $1.759 .875,00$ \\
\hline $\begin{array}{l}691 \text { SÜRDÜRÜLEN FAAL.DÖN.KARI YAS. VERGİ GID. } \\
\qquad 370 \text { DÖN. KARI VERGİ VE DİĞ. YAS. YÜK. KARŞ. } \\
\begin{array}{l}\text { Dönem Vergi Karşılığının } \quad \text { Sürdürülen } \\
\text { Aktarılması }\end{array}\end{array}$ & $100.625,45$ & $100.626,55$ \\
\hline $\begin{array}{l}690 \text { SÜRDÜRÜLEN FAALIYETLER DÖN.KARI VEYA ZARARI } \\
691 \text { SÜRDÜRÜLEN FAAL. DÖN. KARI YAS.VER. GID } \\
693 \text { SÜRDÜRÜLEN FAAL. DÖN. NET KARI VEYA ZAR } \\
\text { Sürdürülen Vergi Hesapları İle Sürdürülen Kar Zarar Hesabının } \\
\text { Sürdürülen Dönem Kar Zarar Hesabına Aktarılması Kaydı }\end{array}$ & $503.132,77$ & $402.506,22$ \\
\hline
\end{tabular}




\begin{tabular}{|l|r|r|}
\hline $\begin{array}{l}\text { 693 SÜRDÜRÜLEN FAAL. DÖN.NET KARI VEYA ZARARI } \\
\text { 699 DÖNEM NET KARI VEYA ZARARI }\end{array}$ & $402.506,22$ & \\
$\begin{array}{l}\text { Dönem Net Kar Zararın Sürdürebilir Dönem Net Kar Zarar Hesabına } \\
\text { Aktarılması }\end{array}$ & & $402.506,22$ \\
\hline $\begin{array}{l}\text { 699 DÖNEM NET KARI VEYA ZARARI } \\
\text { 590 DÖNEM NET KARI }\end{array}$ & $402.506,22$ & \\
Dönem Net Karının Yevmiye Kaydı & $402.506,22$ \\
\hline
\end{tabular}

\subsection{Gelir Tablosu}

İşletmenin TMS 41'e göre yıllık olarak gerçekleştirdiği faaliyet sonucu hazırlanan gelir tablosu aşağıdaki gibidir:

\section{A - BRÜT SATIŞ HASILATI}

2.180.250,00

1 - Yurtiçi Satışlar

$2.180 .250,00$

B - SATIŞLARIN MALIYYTII (-)

$1.759 .875,00$

1 - Satılan Mamuller Maliyeti (-)

$(1.759 .875,00)$

BRÜT SATIŞ KARI VEYA ZARARI

C - ESAS FAALIYYET DÖNEM GIDERLERİ (-)

FAALIYET KARI VEYA ZARARI

$420.375,00$

D - ESAS FAALIYYETLERDEN DİĞER GELİR VE KARZANÇLAR

$82.757,77$

1 - Esas faaliyetlerden diğer çeşitli Gelir ve Kazançlar

$82.757,77$

Tarımsal Faaliyetlerde Değer. Artışları

E- ESAS FAALIYETLERDEN DİĞER GIDER VE ZARARLAR İLE DİĞER FAALIYYTLERDEN GIDER VE ZARARLAR (-)

1- Esas Faaliyetlerden Diğer Çeşitli Gider Ve Zararlar (-)

ESAS FAALIYYET KAR VEYA ZARARI

$503.132,77$

F - FINANSMAN GIDERLERI (-)

SÜRDÜRÜLEN FAALIYETLER DÖNEM KARI VEYA ZARARI

$503.132,77$

G - SÜRDÜRÜLEN FAALIYYETLER DÖN. KARI VERGİ GİDERİ(-)

$(100.626,55)$

1 - Sürdürülen Faaliyetler Dön. Karı Vergi Gideri(-)

$(100.626,55)$

SÜRDÜRÜLEN FAALIYYETLER DÖNEM NET KARI

402.506,22

2019 yılında yapılan faaliyet satışlar sonucunda işletmenin elde ettiği dönem net karı 402.506,22 olarak belirlenmiştir. Gelir tablosu hesapları incelendiğinde işletme ürettiği domatesleri yurt içi piyasasına satışını gerçekleştirmiştir. İşletme yılsonunda yaptığı faaliyetler sonucunda elde ettiği 
sonuçlara göre gelecek dönem planlamalarını yaparken; maliyetlerin azaltılması ve üretimini artırarak daha çok satış yapılması konusunda gayret göstermelidir.

\section{SONUÇ}

Tarım sektörü insanlığın var olmasından bugüne kadar birey ve toplumların beslenme ihtiyacını karşılaması yanında, başka ekonomik sektörlere girdi sağlaması ve istihdam etkisi yaratması nedeni ile her zaman önemini en üst düzeyde tutmuş bir faaliyet alanıdır. Son yıllarda tarımsal alanda faaliyetlerini sürdürmekte olan işletmelerin sayılarının giderek artması neticesinde tarım muhasebesine önemli düzeyde ihtiyaç duyulmaktadır. Tarım işletmelerinde muhasebe uygulamaları ve özellikle maliyet hesaplamaları son derece güçtür. İşletme bünyesinde bulunan gider kalemlerinin ne düzeyde üretimde ne düzeyde farklı yerlerde kullanıldığını belirlemek zor bir durumdur. Tarımsal üretim yapan işletmelerde bu tür zorlukların aşılması ve gerçeğe uygun değerlere ulaşılabilmesi, üretim girdi bileşenlerinin belirlenmesi, üretimde kullanılan işçilik ya da üretim dışı faktörlerin belirlenmesi için etkin bir muhasebe sistemi gerekmektedir. Muhasebe standartları bu zorlukların önüne geçilebilmesi açısından kolaylık sağlamakta olup, ilgili düzenlemeler TMS 41 Tarımsal Faaliyetler standardında belirtilmiştir.

Konu ile ilgili genel bir değerlendirme yapıldığında, tarım işletmeleri açısından muhasebe kayıtlarının ve maliyet hesaplamalarının etkin bir biçimde yapılmadığı anlaşılmaktadır. Çünkü bu tür işletmelerde genellikle gider kalemleri bütün olarak alınıp üretim ve üretim dışı giderler ayırt edilememektedir. Tarımsal ürünlerin elde edilmesi için kullanılan girdi kalemlerinin ne kadarının üretimde ne kadarının idari işlerde kullanıldığı tam olarak bilinmemesinden dolayı maliyet hesaplamaları oldukça güç ve uzmanlık isteyen bir işlem konumuna gelmiştir. TMS 41'e göre seracılık işletmelerinde canlı varlıkların değerlemesinden oluşan değerleme farkları gelir tablosunda gösterilmelidir (Demirkol, 2008). Canlı varlıkların ve canlı varlıklardan hasat edilen tarımsal ürünlerin değerleme farklarının Hazine ve Maliye Bakanlığı tarafından hazırlanan yeni Tekdüzen Hesap Planı Taslağında açılan "643 Tarımsal Faaliyetlerde Değer Artışları" hesabıyla bu boşluk doldurulmuştur. Çalışmada tarımsal faaliyetlere ilişkin maliyetlerin muhasebeleştirilmesinde 7/B maliyet hesapları kullanılmıştır. Çalışmanın sonucunda, üretilen ürünün maliyet değerinin hesaplanmasında, üretim giderleri ve üretim dışındaki giderler ayırt edilerek üretim maliyetlerinin doğru tespit edilmesinin uygulamacılara ve araştırmacılara faydalı olabileceğine kanaat getirilmektedir. Üzerinde durulması gereken bir diğer husus da TMS 41'de yer alan kuralların uygulanmasında mevcut Tekdüzen Hesap Planı'nın yetersiz kalmasıdır. TMS 41'in başarılı bir şekilde uygulanabilmesi için taslak planda bahse konu olan hesapların Tekdüzen Hesap Planına eklenmesi ile beraber Vergi Usul Kanunu (VUK)'nda, amortisman işlemlerini ve değerleme yöntemlerini düzenleyen şartların TMS 41'e göre yeniden düzenlenmesi önerilmektedir. Taslak plandaki hesapların eklenmesi ve VUK'nda değişikliklerin yapılması sonucunda TMS 41'in daha kolay uygulanabileceği ve bu uygulamanın da mali tabloları daha kullanışlı bir hale getireceği düşünülmektedir. Bu nedenle, KGK tarafından hazırlanan yeni taslak hesap planının bir an önce Maliye Bakanlığı tarafından onaylanarak uygulamaya geçirilmesi ve VUK'nda bu konuyla ilgili değişiklik yapılmasının önem arz ettiği düşünülmektedir.

Tarım muhasebesi üzerine geçmişte çok fazla çalışma yapılmamış olmasına rağmen son yıllarda tarım muhasebesi ile ilgili çalışmaların sayılarının giderek arttığı görülmektedir. Yapılan çalışmalar incelendiğinde daha çok büyükbaş hayvancilık işletmeleri üzerinde yoğunlaştığ 1 görülmektedir. Bitkisel üretimin bir dalı olan bahçe bitkileri üretim maliyetlerinin TMS 41 çerçevesinde hesaplanması ve muhasebeleştirilmesi üzerine yapılan bu çalışma ile sera domatesi üretimi yapan bir tarım işletmesinde örnek uygulama çalışması yapılarak tarım muhasebesi 
literatürüne katkı sağlanmaya çalışılmıştır. Çalışmamızın Türkiye'de yapılmış olan diğer çalışmalardan temel farkı; TMS 41 'in temel prensibince üretilen tarım ürünlerinin satılıp satılmadıklarına bakılmaksızın hasat sonrası elde edilen piyasa değerini gerçeğe uygun değeri üzerinden finansal tablolara ve muhasebe kayıtlarına aktarılmaktadır.

\section{KAYNAKÇA}

Arazi Toplulaştırması ve Tarla İçi Geliştirme Hizmetleri Uygulama Yönetmeliği. 30679 Sayılı ve 07.02.2019 Tarihli Resmi Gazete.

Abakay, C. (2019). Tarım İşletmelerinin Muhasebeleştirme Sürecinin İncelenmesi ve TMS 41 Standardı İle Karşılaştırılması: Elmacılık Sektörü Üzerinde Örnek Uygulama". (Yüksek Lisans Tezi), Karamanoğlu Mehmetbey Üniversitesi / Sosyal Bilimler Enstitüsü, Karaman.

Aksoylu, S. (2013). Tarımsal Faaliyetlerin Türkiye muhasebe Standardı 41 (TMS 41)'e Göre Muhasebeleştirilmesi: Gerçeğe Uygun Değer Muhasebesi. Muhasebe ve Denetime Bakış Dergisi, Mart 65-78.

Bağatur, Ç. (2015). Tarımsal İşletmelerin Özgülenmesi. Türkiye Barolar Birliği Dergisi, 1999 (3), 858876.

Çetin, B. ve Tipi, T. (2011). Tarım Muhasebesi. Ankara: Nobel Dağıtım.

Demirkol, Ö. F. (2008). TMS 41 Kapsamında Seracılık Faaliyetlerinde Muhasebe Kayıt Sürecine İlişkin Genel Bir Değerlendirme. Muhasebe ve Vergi Uygulamaları Dergisi, 1 (1), 115-121.

Doğan, S. (2018). Türkiye İçin Tarımın Önemi. Ziraat Mühendisleri Odası Önceki Genel Başkanı Sunumu.

Erdoğan, G. (2004). Tarımsal İşletmelerde Kredi Taleplerinin Doğrusal Programlama Yöntemiyle Belirlenmesi Kırşehir İli Merkez İlçesi Tarım İşletmeleri Araştırması. Ankara: Tarım ve Köyişleri Bakanlığı Tarımsal Ekonomi Araştırma Enstitüsü. Yayın No:121

Hacıhasanoğlu, T. ve Ünlü, A. (2017). Canlı Varlıkların TMS 41 ve Tekdüzen Muhasebe Sistemine Göre Muhasebeleştirilmesi: Süt Üretim İşletmesi Uygulaması. International Journal of Academic Value Studies, 3 (9), 394-410.

Hatunoğlu, Z. ve Kıllı, M. (2016). Tarım İşletmelerinde Bitkisel Üretim Maliyetlerinin TMS 41 Çerçevesinde Muhasebeleştirilmesi. Kahramanmaraş Sütçü İmam Üniversitesi Sosyal Bilimler Dergisi, 13 (1).

Kamu Gözetimi Muhasebe ve Denetim Standartları Kurumu (KGK), (26.12.2018). Finansal Raporlama Standartları Yeni https://www.kgk.gov.tr/Portalv2Uploads/files/Duyurular/v2/ TFRS/EK2_Finansal\%20Raporlama\%20Standartlar\%C4\%B1na\%20Uygun\%20Hesap\%20 Plan\%C4\%B1\%20Tasla\%C4\%9F\%C4\%B1.pdf (Erişim Tarihi: 05. 04. 2021).

Kıllı, M. (2014). Tarım İşletmelerinde Tarımsal Faaliyet Standardı Çerçevesinde Maliyet Hesaplaması: Bir Tarım İşletmesinde Örnek Uygulama. (Doktora Tezi), Kahramanmaraş Sütçü İmam Üniversitesi / Sosyal Bilimler Enstitüsü, Kahramanmaraş.

Nergiz, M. (2013). Tarımsal Faaliyetler ve Canlı Hayvan Yetiştiriciliği Konularıyla İştigal Eden İşletmelerde Stoklar Muhasebe Ve Maliyet Muhasebesi Uygulamaları (TMS 2 Ve TMS 41 Çerçevesinde). (Yüksek Lisans Tezi), Kahramanmaraş Sütçü İmam Üniversitesi/Sosyal Bilimler Enstitüsü, Kahramanmaraş. 
Örten, R., Kaval, H. ve Karapınar, A. (2017). Türkiye Muhasebe-Finansal Raporlama Standartları Uygulama ve Yorumları (10. Baskı), Ankara: Gazi Kitabevi.

Sönmez, F. (2004). Tarımsal Faaliyetlerin Muhasebeleştirilmesi (25 No'lu SPK Tebliğinin 31. Kısım Hükümleriyle Desteklenmiş Olarak). Mali Çözüm, (69), 143-163.

Tokay, S. H ve Deran, A. (2011). Tarım Sektöründe ve Tarım Sektörünün Önemli Bir Alt Dalı Olan Meyve Bahçesi İşletmelerinde Muhasebenin Gereği, Belge ve Defter Düzeni. Niğge Üniversitesi İ̈BF Dergisi, 4 (1), 40-55.

Tuna, Y. (1993). Tarımda Verimlilik Artışının Ekonomik Sonuçları: Türkiye İle İlgili Bir Değerlendirme. Ankara, Milli Prodüktivite Merkezi Yayınları, No:487.

Türkiye İstatistik Kurumu (TÜIKK) (2019). https://tuikweb.tuik.gov.tr/PreHaberBultenleri.do?id= 24869 19.04.2018, (Erişim Tarihi 12.04.2021).

Türkiye Muhasebe Standartları (TMS 41) Tarımsal Faaliyetler Standardı 2020. 